\title{
The Commercial Buildings in Central Asia during the Tenth A.H / Sixteenth A.D Century
}

"A comparative Architectural Archaeological Study"

\section{The Commercial Buildings in Central Asia during the Tenth A.H / Sixteenth A.D Century "A comparative Architectural Archaeological Study"}

\author{
Mahmoud Roshdy \\ Lecturer in Islamic dept., Faculty of Archaeology, Cairo Univ. \\ e-mail: mahmoud_roshdy50@yahoo.com
}

\begin{abstract}
Central Asia includes a lot of commercial buildings, the oldest of Khans of which date back to the early Islamic era, while the oldest in Central Asia date back to the period of Alqura Khanyeen(226 -609A.H / 840-1212A.D) In addition, a lot of the plans of the khans from the tenth to sixteenth century consisted of one floor that included an octagonal hall covered with a central dome abutted on Turkish triangles. This protrudes the importance of these khans and their plans by back tracing the architectural motifs and units included in these khans. This study conducts a comparison between these khans and the contemporary ones in Iran and Anatolia in terms of their plans, diagrams and figures reflecting the similarities and differences among the plans, the architectural motifs, and the architectural units.
\end{abstract}

KEYWORDS: central Asia, Bukhara, Khan, Façade, Portal, Dome, Arch

\section{INTRODUCTION}

In Central Asia, (Hippenreiter, 1985, P104:159). during the first centuries after the Islamic conquest, a huge number of Khans (Heneda, \& Miura, 1994, P 218) (Ibn Manzour, 1993, P146) (Al-Razi , 1973, P194) . outspread on the main trade routes to connect them with the forts that outstretched or to the towers. Private pavilions belonged to the nobles during the pre Islamic era in this area where Al-Narshkhi (Al-Narshakhi, 1993, P36). mentioned that "there were a lot of Ribats on at the entrance of Beqand (Abo el-Fida, 1840, P489). till 240 A.H - 854 A.D, reaching more than one thousand ribat; the number of the villages of Bukhara. (Al-Bostani, 1887, P401). The oldest of Khans in Central Asia dated back to the period of Al- Qura Khanyeen (226 -609A.H / 840-1212A.D) (Al-Ghamedi , 1990, P242:243). where Shams El Molok al-Sultan Nasr Ibn Ibrahim died in 492 A.H - 1098 after building two Khans; one of them was located on the route of Bukhara - Samarqand and (Al-Qazwini, 1960, P535). (AlHamawi, 1906, P533) the other on the route of Samarqand - Khoganda. (Al-Khangi , 1907, P183). The most common Khan was under the name of Ribat Al - Malik on the route of Bukhara - Samarqand, which was built in 471 A.H - 1079 A.D. (Aslanabah, 1987, P19).

Central Asia "Uzbekistan" (Jumabaye , 1992, P36:43 ) included a number of Khans that dated back to the $10^{\text {th }}$ A.H. / $16^{\text {th }}$ A.D. century. Their plans consisted of one floor that contains an octagonal room covered, known as the kiosk, with a central dome in the middle supported by 
Turkish triangles formed from the intersection of the pointed arches. In the drum of the dome, there were arched windows with pointed arches alternated with closed niches with pointed arches. At each side of the octagonal room, an arched closed niche alternated with niches of pointed arches. In each niche, a rectangular corridor can be found divided into two square areas covered with a dome supported by Turkish triangles. On both sides of the first square area there is an opening with a pointed arch leading to the other square areas covered with domes opening into each other and connected to the main corridors. In the second square area, in Toki- Zargaron in Bukhara (Fig. 1), there is a closed opening on each side with a pointed arch between them opening to a plain high entrance at each side of the Khan. On the other hand, in Tim of Abdulla Khan (Fig. 2), there are closed niches at each side with pointed arches, in addition to three memorial projecting entrances, the biggest of which is located in the middle of the main façade. The Khans were built of fired brick and covered with domes from the outside. In the middle of some of the khans, octagonal pavilions were found at each side, as well as windows with pointed arches. Yet, there were no towers at their corners (Ragab, 2017, P151:161).

In the past, the Khan consisted of a number of rooms surrounded by an open court that mostly contained two floors. The ground floor included the riding stables, storerooms, and small shops in the form of hollow niches in the wall that included shelves for goods and a place for the seller and the buyer. The second floor was allotted for the travelers to rest inside a number of rooms. The Khan also included a hall for prayer and sources for water. (Badr , 2002, P35:40) It is usually square or rectangular in shape with a plain hall projecting a memorial portal with towers at its corners.

\section{The Analytical Study}

\subsection{The Design}

The design of Khans in Central Asia varied among them the following :

1 - Khans with one central court as in Ribat Al- Malik located on the route of Bukhara Samarqand (471 A.H / 1079 A.D). It consists of a square area of $86 \times 86 \mathrm{~m}$ built of mud brick and covered with fired brick. Its rooms and halls were distributed onto two floors around the central court with vaulted roofs. The only remaining part of this Khan is the southern wall and the entrance. The wall was supported by semi circular towers around its corners, divided by huge semi circular supports crowned by a series of pointed arches.

2 - Khans that included a doubled court as in Ribat Sharaf (508 A.H / 1114 A.D) and some other Khans provided with a series of housing private vaulted rooms as in Ribat Al- Malik (471 A.H / 1079 A.D). In this type, the outer court was used as a Khan while the inner court was used by the Sultan and the high officials, which was due to the nature of the wandering life of Sultans during this period, making those buildings desirable.

3 - Khans that included a covered hall, known as the kiosk. This type proceeded with the same style that prevailed in Central Asia during the $10^{\text {th }}$ A.H $/ 16^{\text {th }}$ A.D century, along with the appearance of another style represented in the disappearance of the main elements and the central court. Thus, the plan of the Khan became multi sided in form. In its center, an octagonal area can 


\section{The Commercial Buildings in Central Asia during the Tenth A.H / Sixteenth A.D Century \\ "A comparative Architectural Archaeological Study"}

be found, covered by a huge dome supported by Turkish triangles formed from the intersecting pointed arches. In the four sides of the hexagonal outer shape, there is a memorial entrance leading to a corridor divided into square areas through groups of intersecting pointed arches. These areas were covered with small shallow domes supported by Turkish triangles. The corridors led to the central octagonal area as in Toki - Zargaron, Tim Abdulla Khan in Bukhara $\left(10^{\text {th }}\right.$ A.H $/ 16^{\text {th }}$ A.D ), in addition to Toki Sarrafon, and Toki Tilbak Furushon in Bukhara in $\left(10^{\text {th }}\right.$ A.H $/ 16^{\text {th }}$ A.D) (Arapov, 2006, P70:73).

\subsection{Architectural units}

\subsubsection{Facades}

The Khans of this period were distinguished by having a multitude of facades where they contained four free facades as found in Tim Abdulla Khan $\left(10^{\text {th }}\right.$ A.H $/ 16^{\text {th }}$ A.D) and Toki Zargaron (10 ${ }^{\text {th }}$ A.H $/ 16^{\text {th }}$ A.D) ( Pl. 1,2) . The south western side is considered the main façade, built from plain fired brick, while some Khans included axial entrances as in Toki Zargaron ( $10^{\text {th }}$ A.H $/ 16^{\text {th }}$ A.D) and others included a memorial entrance as in Tim Abdulla Khan $\left(10^{\text {th }}\right.$ A.H $/ 16^{\text {th }}$ A.D). It can be noticed that those facades did not include corner towers, as some Khans included an axial entrance in the middle of the four main facades as in Toki Zargaron ( $10^{\text {th }}$ A.H / $16^{\text {th }}$ A.D) and other ones included a memorial entrance in the four main facades as in Tim Abdulla Khan $\left(10^{\text {th }}\right.$ A.H / $16^{\text {th }}$ A.D). Those entrances were open to the corridors that led to the covered hall directly.

\subsubsection{Portals}

The portals of the Khans varied during this period, but there are two types as follows: 1 - Projecting memorial portals in the middle of the main façade consisting of a niche with a pointed arch crowning the portal. Its inside is smooth made of stalactites, with an entrance opening leading to the building and higher than the façade as found in Tim Abdulla Khan $\left(10^{\text {th }}\right.$ A.H / 16 ${ }^{\text {th }}$ A.D) (Pl. 3 ) that contains three memorial portals, the biggest of which lies in the middle while the other two are smaller and lower.

2- Axial portals consist of an opening with a pointed arch that is a little higher than the façade leading directly to a corridor opening to the covered hall as in Toki - Zargaron $\left(10^{\text {th }}\right.$ A.H $/ 16^{\text {th }}$ A.D) (Pl .4 ).

\subsubsection{Domes}

They varied between either a central pointed plain dome in the middle that is bigger and higher with a number of arched windows in its drum, or the other form which has an octagonal pavilion with semi and shallow domes at the sides. Transition areas of the domes consisted of Turkish triangles converting the square into an octagon through the intersection of the arched niches as in Toki - Zargaron (10 ${ }^{\text {th }}$ A.H / $16^{\text {th }}$ A.D) and in Tim Abdulla Khan (10 ${ }^{\text {th }}$ A.H / $16^{\text {th }}$ A.D) ( Pl . $5,6,7$ ). In addition, it can be noticed that the drums of domes were somehow small, and some 
domes included pavilions (Al-Hadad, 1993, P143) in the middle that are name the dome with pavilion. This variety appeared in various areas Central Asia, where the corridors were covered with shallow domes supported by Turkish triangles, which were among the most common coverings used in the $10^{\text {th }}$ A.H / the $16^{\text {th }}$ A.D. century.

\subsubsection{Arches}

Khans included a varied group of pointed arches which was considered a main feature in Central Asia where they were used in the niches of square areas and the covered hall in the Khan, in addition to the main portal and axial portal, and the helmets of main domes as well as the windows, closed niches, and drums of domes in the middle of the walls of Khans in Toki Zargaron (10 ${ }^{\text {th }}$ A.H / $16^{\text {th }}$ A.D) and Tim Abdulla Khan (10 ${ }^{\text {th }}$ A.H / 16 ${ }^{\text {th }}$ A.D) ( P1 . 8,9 ). This arch was one of local influences that can be found in the dome of Ismail Al-Samani $\left(3-4^{\text {th }}\right.$ A.H / 9-10 ${ }^{\text {th }}$ A.D) " (Retviladzi , 1995, P15) (Smith , 1982, P32) then appeared on the main façade at the mosque of Namazgah $\left(6^{\text {th }}\right.$ A.H / 12 ${ }^{\text {th }}$ A.D) (Knobloch, 1972, P167) in Bukhara, in the dome of Gor Amir (803 A.H / 807 A.D), and in 1400 A.D / 1404 A.D. (De George \& Porter, 2002, P116) ( McChesney 1987, P169) in Samarqand, as well as in the Madrasa of Kokaltash (976 - 977 A.H / 1568 - 1569 A.D) in Bukhara .

\subsubsection{Windows}

Shapes of windows were rectangular pointed arched with stucco decorations in geometric styles varied between hexagonal shapes and octagonal shapes like a hive as well as intersecting circles . most of these windows found in the drums of central domes alternated with closed niches .These windows having a functional importance in airiness and providing a renewable circulation of air without any strong currents and reducing the pressure of height .

\section{The Influences}

Plans were similar in Central Asia and Iran, in which a lot of them were found in Iran in the $5^{\text {th }}-$ $6^{\text {th }}$ A.H $/ 11^{\text {th }}-12^{\text {th }}$ A.D century, as Zindan Horan, Khans of north eastern Iran, as the castle of Akka and Ribat Sharq that was finished in 549 A.H / 1154 A.D, and as Ribat Karim. Also, there was Ribat Turk in Central Asia that had a military nature and a defensive plan, in which the housing part was secondary (Hillenbrano, 2004, P338:339).

The origin of Khans in Iran dated back to parts of buildings in Central Asia from pre-Islam as Al - Kasha or the palace or the fortified house, in which there were a lot of Khans in Iran and in Central Asia as Ribat Sultan and a lot of trade stations in medieval ages in Sebastian. The most important of these Khans were the ones in the east of Khurasan and Turkmanstan as Ribat Malik 470 A.H / 1087 A.D, Ribat Mahir, the castle of Kasha, and Ribat Sharaf (508 A.H / 1114 A.D). On the other hand, Ottoman Khans were found to have consisted of a court "Qafarbena Khan" (948 A.H / 1541 A.D) that contained a court and one riwaq. This style was in Aghadeer Khan (607 - 616 A.H / 1210 - 1220 A.D), which may be due to its simplicity and flexibility. It was, in fact, common in the Ottoman period(Hillenbrano, 2004, P353).Khans that consisted of one court 


\section{The Commercial Buildings in Central Asia during the Tenth A.H / Sixteenth A.D Century \\ "A comparative Architectural Archaeological Study"}

were only common in the Ottoman period, due to their simplicity. They consisted of at least two floors and sometimes had two or three courts, as in Boyok Faled Khan (1060 A.H / 1650 A.D) they had no stock for rides. The subjoined rooms were used for storing or as shops, and rarely as stables. The rooms in the upper floor were planned and divided into living rooms with open windows in the outer wall as in By Khan in Borsa. The portal included towers at the corners. There were also fountains or mosques in the middle of the court, as in Abek Khan in Borsa, that had both together as well as rooms surrounding portals for the officials responsible for the building, which was main feature in the building (Baipakov, 1998, P174).

\section{Conclusion}

The design of Khans in Central Asia varied, among of which were the following: Khans with one central court as in Ribat Al- Malik located on the route of Bukhara - Samarqand (471 A.H / 1079 A.D).

1- Khans that included a doubled court as in Ribat Sharaf (508 A.H / 1114 A.D) and some other Khans provided with a series of housing private vaulted rooms as in Ribat AlMalik (471 A.H / 1079 A.D).

2- Khans that included a covered hall, known as the kiosk. This type proceeded with the same style that prevailed in Central Asia during the $10^{\text {th }}$ A.H. $/ 16^{\text {th }}$ A.D. century, along with the appearance of another style represented in the disappearance of the main elements and the central court as found in Toki - Zargaron (10th A.H. / 16thA.D.) and Tim Abdulla Khan ( $10^{\text {th }}$ A.H. / $16^{\text {th }}$ A.D. $)$.

3- The Khans of this period were distinguished by having a multitude of facades where they contained four free facades as found in Toki - Zargaron $\left(10^{\text {th }}\right.$ A.H. $/ 16^{\text {th }}$ A.D. $)$ and Tim Abdulla Khan (10 ${ }^{\text {th }}$ A.H. / $16^{\text {th }}$ A.D.).

4- The portals of the Khans varied during this period, but there are two types as follows: Projecting memorial portals in the middle of the main façade consisting of a niche with a pointed arch crowning the portal, as found in Tim Abdulla Khan (10th A.H. / 16th A.D.), Axial portals that consisted of an opening with a pointed arch that is a little higher than the façade leading directly to a corridor opening to the covered hall as in Toki-Zargaron $\left(10^{\text {th }}\right.$ A.H. $/ 16^{\text {th }}$ A.D. $)$.

5- Domes varied between either a central pointed plain dome in the middle that is bigger and higher with a number of arched windows in its drum, or the other form which has an octagonal pavilion with semi and shallow domes at the sides.

6- Khans included a varied group of pointed arches which was considered a main feature in Central Asia where they were used in the niches of square areas and the covered hall in the Khan. 


\section{References}

1. Abo el-Fida, A. (1840) Countries calendar, Dar Al-Tibaa Al-Sultaniya, Paris.

2. Al-Bostani, A. (1887) Encyclopedia, Vol.1, Dar Al-Maaref, Beirut.

3. Al-Ghamedi, M. (1990) Relationships between Al-Qura Khanyeen and Turkistan with neighboring Islamic countries and their role in expansion of Islam " 382 -482 A.H - 992 - 1089 A.D " the magazine of Om Al-Qura University , third year, macca.

4. Al-Hadad, M. (1993) The domes in the Egyptian Islamic architecture, Maktabet Al-Sakafa AlDinya, Cairo.

5. Al-Hamawi, S. (1906) Glossary of countries, Vol.5, first edition, Al-Saada print house, Cairo.

6. Al-Khangi , M. (1907) Al-Omran mine in Al-Mustadrak on the lexicon of countries, Vol.10, first edition, Press of happiness, Egypt .

7. Al-Narshakhi , A. (1993) History of Bukhara " 286 - 348 A.H -- 899 - 959 A.D " commented by Amin Abd al-Hamid Badawy, Nasr Allah Al-Shirazi, edition 3, Dar Al-Maaref, cairo.

8. Al-Qazwini, A. (1960) The effects of the country and the news of slaves Dar Sader, Beirut.

9. Al-Razi , M . (197) Mokhtar al-Sahah, educated by Mahmoud Khater, Dar Al-Maaref, Cairo.

10. Arapov, A. (2006) Bukhara, Masterpieces of Central Asia, Institute Of Architecture, Tashkent .

11. Aslanabah, O. (1987) Turks arts and their structures, translated by Ahmed Esaa , first edition , Research Center for Islamic History, Arts and Culture, Istanbul .

12. Badr , M. (2002) the influence of Seljuq culture on the countries of eastern Islamic world, Ayubid and Mamluke in Egypt, vol.2, first edition, Zahraa Al- Sharq, Cairo .

13. Baipakov, K. (1998) History of civilizations of Central Asia, Volume IV, Published by UNESCO, Imprimerie Darantiere, Paris.

14. De George, G., Porter, Y . (2002) The Art of Islamic Tile, Flammarion, Paris.

15. Heneda, N ., Miura, T. (1994) Islamic Urban Studies, Kagan Paul International, London and New York.

16. Hillenbrano, R. (2004) Islamic Architecture, The American University, Cairo.

17. Hippenreiter, B. (1985) Central Asia , Izdatelstvo Planet, Moscow .

18. Ibn Manzour, H. ( 1993) Arab Language, Dar Sader, Bairut.

19. Jumabaye , F. (1992) History of uzbek, Institute Of Architecture, Tashkent .

20. Knobloch, E . (1972) Beyond the Oxus, Archaeology, Art, Architecture of Cnteral Asia, Benn, London .

21. Ragab, A.,(2017). Islamic archaeology \& culture in Bukhara, vol 2, Kuwait Center for Islamic Arts , Kuwait .

22. Retviladzi , L. ( 1995) Islamic monuments in Uzbekistan, Univ. of Orientalism, Tashkent .

23. Smith , H. (1982) Bukhara, progress publishers, Moscow .

24. Zahidov, (1.s). Architectural history, Tashkent, 2012. 
The Commercial Buildings in Central Asia during the Tenth A.H / Sixteenth A.D Century "A comparative Architectural Archaeological Study"
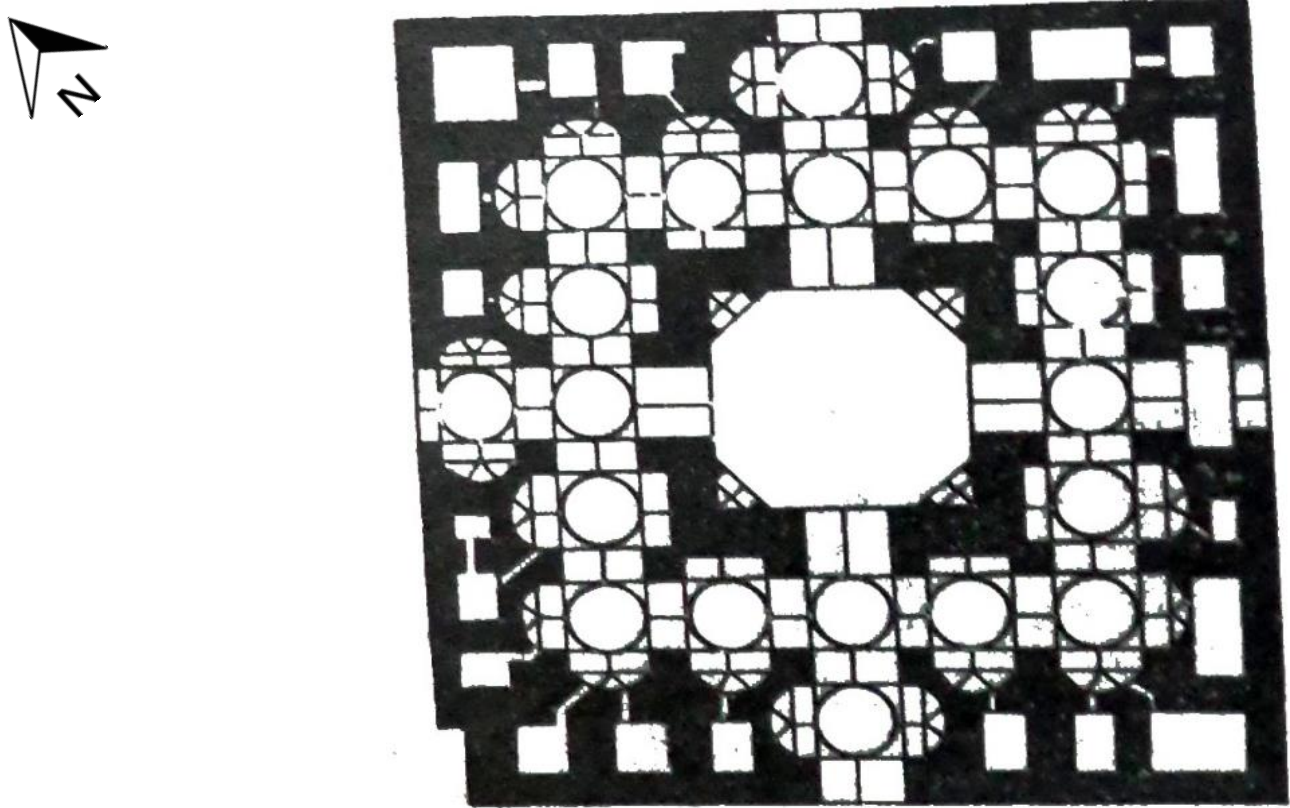

Fig .1 Plan of the Toki-Zargaron in Bukhara, $10^{\text {th }}$ A.H. $/ 1^{\text {th }}$ A.D.

Zahidov, (l.s) . Architectural history, Tashkent , 2012, P114
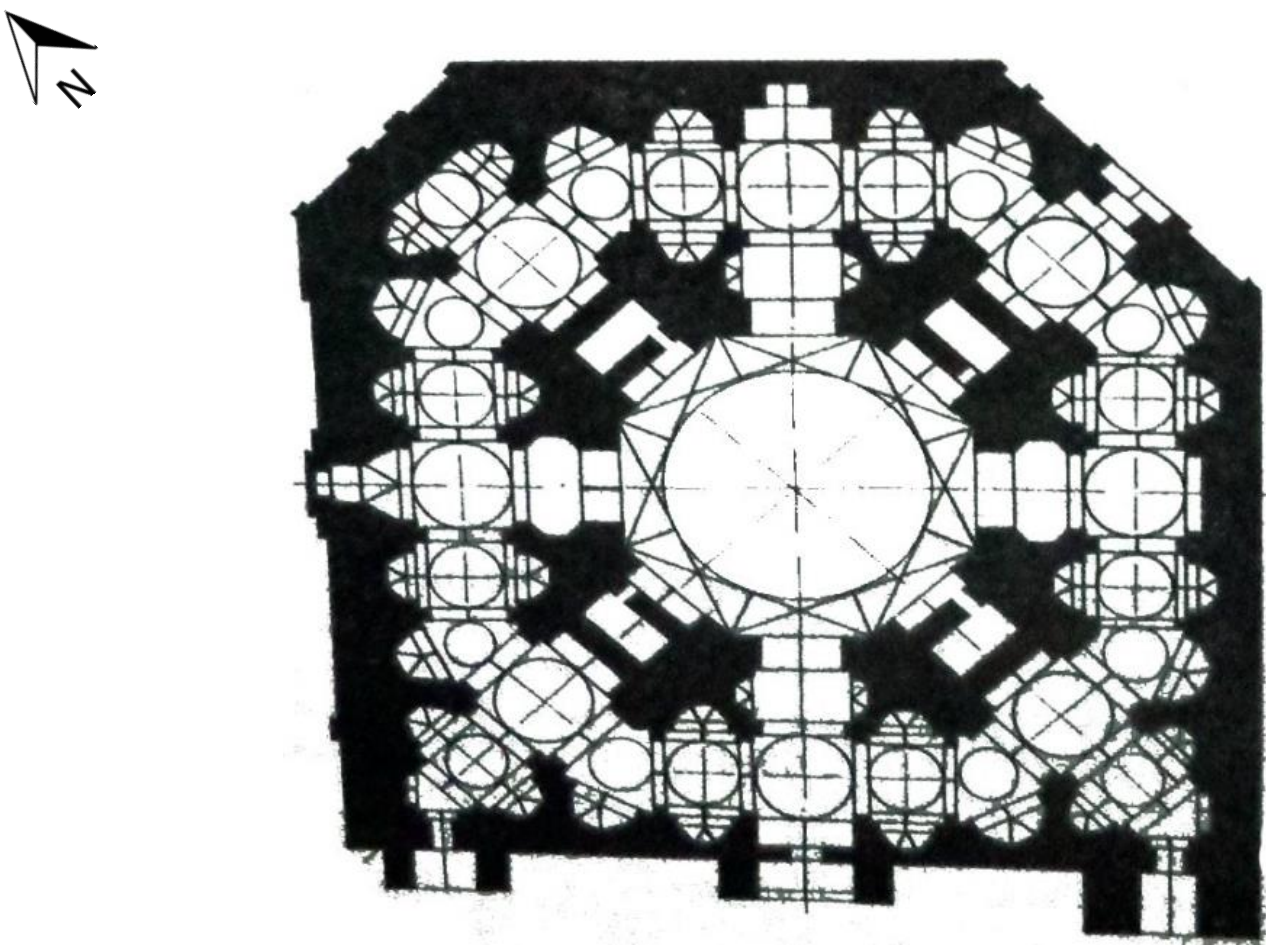

Fig. 2 plan of the Tim of Abdulla-Khan in Bukhara, $10^{\text {th }}$ A.H. $/$ 16 $^{\text {th }}$ A.D. Zahidov , Architectural history, P75 . 


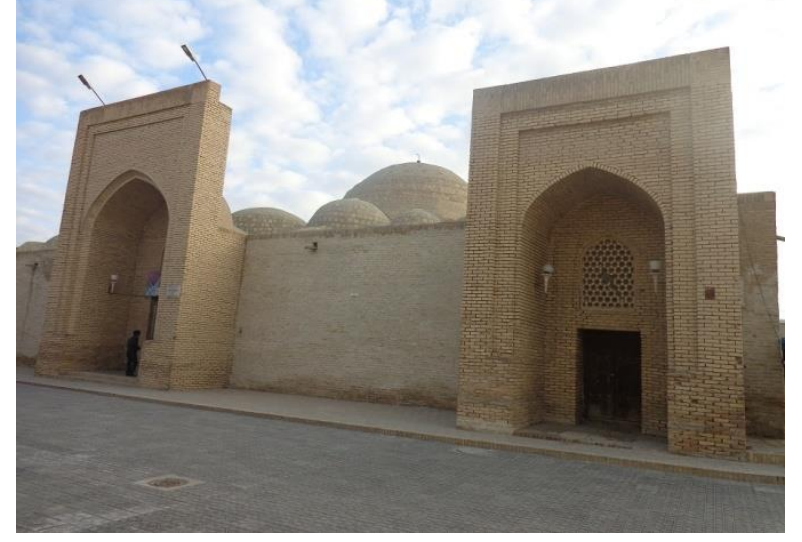

Pl. 1 The main façade in Tim of Abdulla - Khan (Photographed by the researcher)

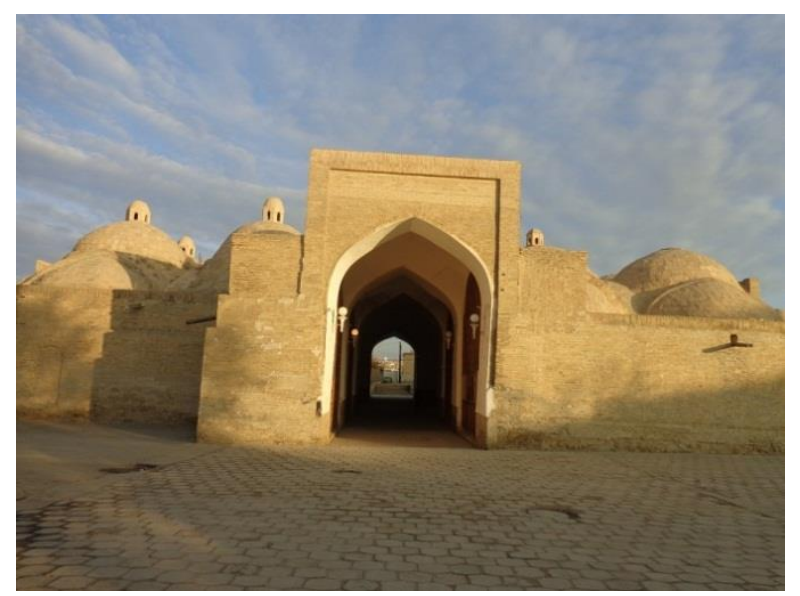

Pl. 2 The Main Façade of Toki-Zargaron (Photographed by the researcher)

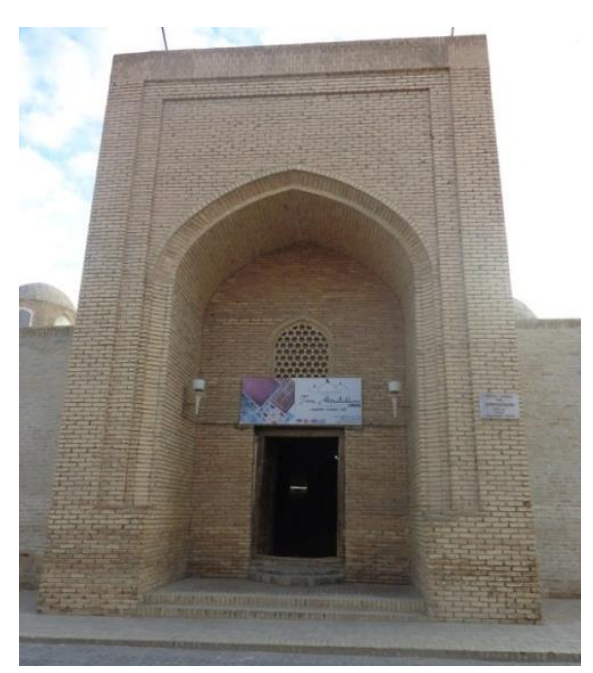

Pl. 3 The monumental memorial entrance in Tim of Abdulla - Khan (Photographed by the researcher) 


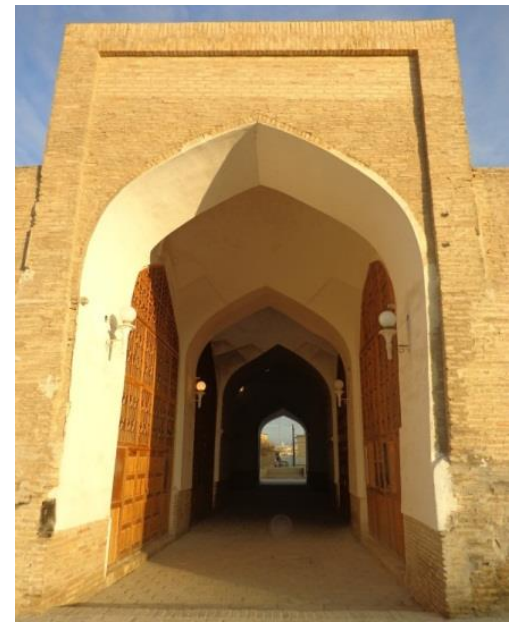

Pl. 4 Axial portals in Toki-Zargaron

(Photographed by the researcher)

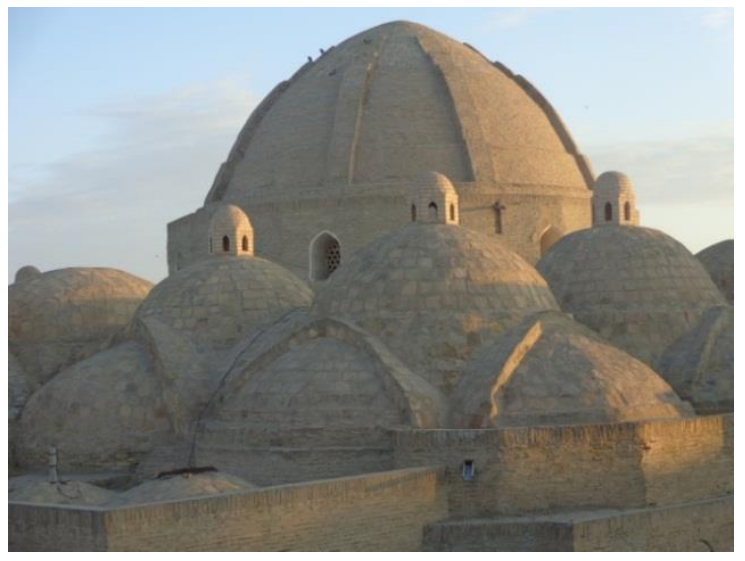

Pl. 5 The Central Dome in Toki-Zargaron (Photographed by the researcher)

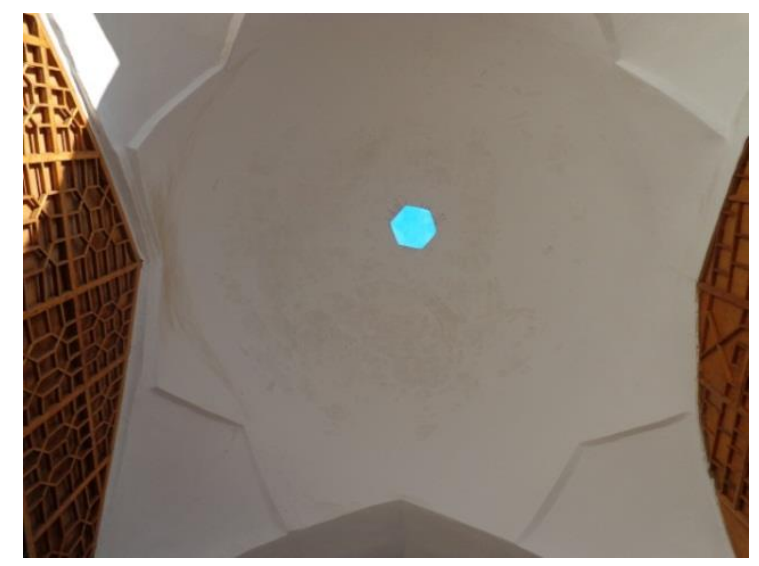

Pl. 6 The Central Dome in Toki-Zargaron (Photographed by the researcher) 


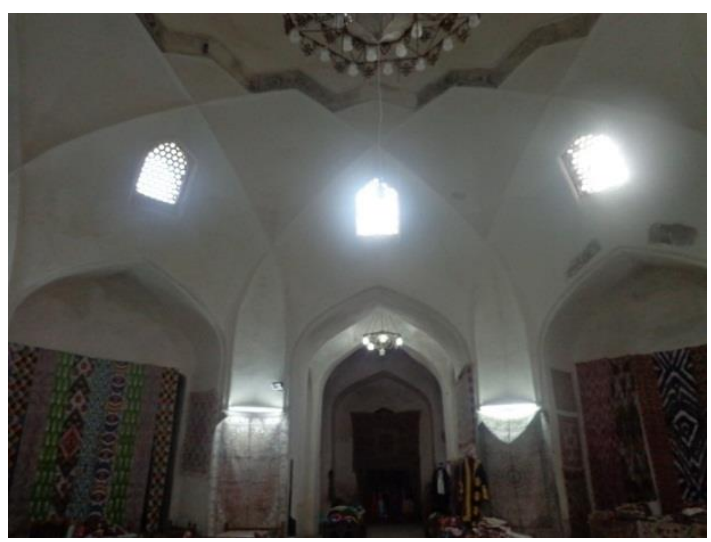

PI. 7 The Central Dome in Tim of Abdulla-Khan (Photographed by the researcher)

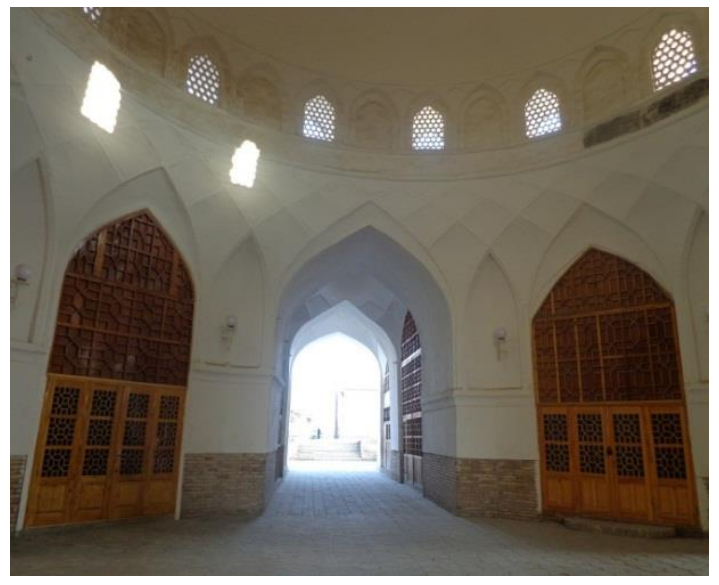

PI. 8 Arches in Toki-Zargaron (Photographed by the researcher)

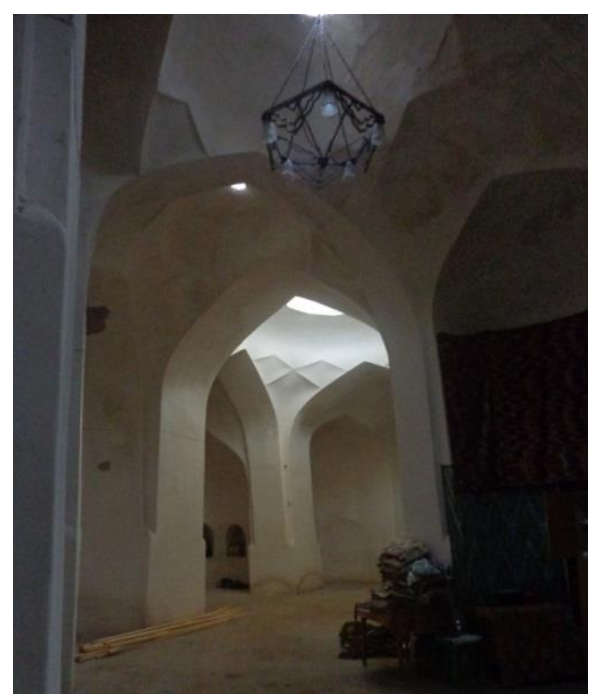

PI. 9 Arches in Tim of Abdulla-Khan (Photographed by the researcher) 